VARIABEL VOL. 2 NO. 1 (2019): 9-15

p-ISSN: 2593-302X dan e-ISSN: 2599-3038

This work is licensed under

a Creative Commons Attribution-NonCommercial 4.0 International License.

\title{
Efektivitas Model Pembelajaran Kooperatif Tipe Teams Games Tournaments untuk Meningkatkan Kemampuan Pemahaman Konsep Matematis Siswa pada Materi Himpunan Kelas VII SMP Negeri 9 Singkawang
}

\author{
Vinasari Nurbayanti ${ }^{1}$, Resy Nirawati ${ }^{2}$, Mariyam $^{3}$ \\ Program Studi Pendidikan Matematika, STKIP Singkawang, Singkawang, Indonesia \\ visa0472@gmail.com ${ }^{1}$, resynirawaty@gmail.com ${ }^{2}$, mariyam.180488@gmail.com
}

\begin{tabular}{|c|c|}
\hline $\begin{array}{l}\text { Kata Kunci: } \\
\text { Pembelajaran Kooperatif, } \\
\text { Teams Games Tournaments, } \\
\text { Pemahaman Konsep } \\
\text { Matematis, Himpunan }\end{array}$ & $\begin{array}{l}\text { ABSTRAK } \\
\text { Penelitian ini bertujuan untuk mengetahui efektivitas } \\
\text { model pembelajaran Teams Games Tournaments (TGT) } \\
\text { kemampuan pemahaman konsep matematis siswa pada } \\
\text { materi himpunan kelas VII SMP Negeri } 9 \text { Singkawang. } \\
\text { Penelitian ini merupakan penelitian true experiment } \\
\text { dengan desain penelitian pretest posttest control group } \\
\text { design. Populasi penelitian ini adalah seluruh siswa kelas } \\
\text { VII SMP Negeri } 9 \text { Singkawang, dan ditentukan dengan } \\
\text { teknik simple random sampling. Sampel penelitian ini } \\
\text { adalah kelas VII A sebagai kelas eksperimen yang } \\
\text { menggunakan model pembelajaran TGT, dan VII B } \\
\text { sebagai kelas kontrol yang menggunakan model } \\
\text { pembelajaran langsung. Instrumen atau teknik } \\
\text { pengumpulan data yang digunakan yaitu tes kemampuan } \\
\text { pemahaman konsep, lembar pengamatan aktivitas dan } \\
\text { angket motivasi. Teknik analisis data yang digunakan } \\
\text { untuk mengetahui perbedaan peningkatan pemahaman } \\
\text { konsep matematis siswa di kelas kontrol dan kelas } \\
\text { eksperimen yaitu dengan mrenggunakan uji-t, untuk } \\
\text { mengetahui aktivitas siswa yaitu dengan menggunakan } \\
\text { persentase aktivitas siswa per indikator dan untuk } \\
\text { mengetahui motivasi belajar siswa menggunakan rata-rata } \\
\text { dari skor angket yang diberikan. Berdasarkan analisis } \\
\text { data yang diperoleh dan dianalisis menggunakan uji-t dua } \\
\text { sampel diperoleh thitung } 16,44 \text {, sedangkan tabel } 5 \% \\
\text { dengan dk } 54 \text { adalah } 2,00 \text { sehinggat } t_{\text {hitung }}>\text { tabel. } \\
\text { Hasil penelitian menunjukkan bahwa kemampuan } \\
\text { pemahaman konsep matematis siswa kelas yang } \\
\text { menggunakan model pembelajaran Teams Games } \\
\text { Tournaments lebih efektif dibanding kelas yang } \\
\text { menggunakan pembelajaran langsung. Aktivitas siswa } \\
\text { diperoleh rata-rata sebesar } 80,26 \% \text {, dengan kategoriaktif } \\
\text { dan motivasi belajar siswa diperoleh rata-rata sebesar } \\
74,17 \text { dengan kategori tinggi. }\end{array}$ \\
\hline
\end{tabular}




\section{PENDAHULUAN}

Matematika merupakan ilmu dasar yang mempunyai peran penting dalam ilmu pengetahuan, teknologi dan di dalam kehidupan sehari-hari. Selain itu, pelajaran matematika merupakan pelajaran yang meningkatkan daya pikir manusia. Setiap individu memiliki kemampuan yang berbeda-beda dalam memahami dan mengerti unsur-unsur matematika. Unsur-unsur matematika yaitu dapat dilihat dari banyaknya definisi, penggunaan simbol-simbol dan rumus-rumus yang bervariasi (Nawafilah, 2015:2).

Mata pelajaran matematika akan lebih mudah dipelajari apabila siswa mampu menguasai konsep matematika, pada saat yang sama siswa juga harus menguasai konsep-konsep sebelumnya. Hal ini dikarenakan tujuan pembelajaran matematika adalah pembelajaran matematika harus praktis dengan tidak mengabaikan keharusan pemahaman konsep yang merupakan pola struktur matematika (Hendriana dan Soemarmo, 2014:7). Sehingga, proses pembelajaran matematika akan tampak masuk akal dengan struktur yang sederhana. Berdasarkan pernyataan tersebut, terlihat bahwa kemampuan pemahaman konsep matematis siswa merupakan hal penting dalam pembelajaran matematika.

Kemampuan pemahaman konsep matematis siswa Indonesia dinyatakan rendah, hal ini diperkuat oleh penelitian yang dilakukan oleh Isrotun (2014:5) yang menunjukkan bahwa pemahaman konsep matematika pada siswa MTs Negeri Surakarta II selama ini masih rendah. Berdasarkan hasil penelitian Isrotun menunjukkan kemampuan siswa menyatakan ulang sebuah konsep sebesar 30\%, kemampuan siswa membedakan contoh dan non contoh sebesar $17,5 \%$, dan kemampuan siswa mengklasifikasi objek menurut sifat tertentu sebesar $20 \%$.

Hal ini diperkuat pra riset yang dilakukan peneliti yang mengandung indikator pemahaman konsep pada materi himpunan kepada 28 siswa di kelas VII. Dari 3 indikator pemahaman konsep matematis siswa yang meliputi indikator menyatakan ulang sebuah konsep, mengklasifikasikan obyek menurut sifat-sifat tertentu, dan mengaplikasikan konsep atau algoritma pemecahan masalah, dapat disimpulkan bahwa pemahaman konsep matematis siswa kelas VII di SMP Negeri 9 Singkawang masih rendah.

Selain itu, hasil observasi aktivitas siswa dan motivasi belajar siswa yang diperoleh saat proses belajar mengajar berlangsung di SMP Negeri 9 Singkawang juga masih rendah. Rendahnya aktivitas dan motivasi belajar siswa dikarenakan model pembelajaran yang digunakan guru kurang tepat dalam proses pembelajaran.Berdasarkan hasil pengamatan penulis di SMP Negeri 9 Singkawang, Model pembelajaran yang digunakan guru untuk mengajar menggunakan model pembelajaran langsung. Model pembelajaran langsung adalah model pembelajaran yang dirancang secara khusus untuk menunjang proses belajar siswa berkenaan dengan pengetahuan prosedural dan pengetahuan deklaratif yang terstruktur dengan baik dan dapat dipelajari selangkah demi selangkah (Jihad dan Haris, 2008;27).

Dilihat dari permasalahan di atas bahwa model pembelajaran langsung belum sepenuhnya tepat, sehingga diperlukan adanya perubahan dalam model pembelajaran. Model pembelajaran yang digunakan dalam pembelajaran matematika seharusnya dapat menumbuhkan minat siswa untuk belajar. Selain itu, model pembelajaran yang digunakan harus menyenangkan dan bermakna agar siswa yang mengikuti proses belajar mengajar tidak bosan dan dapat mengikuti pelajaran dengan baik. Sehingga dengan adanya perubahan model pembelajaran yang tepat dapat meningkatkan pemahaman konsep matematis siswa dan dapat mempengaruhi aktivitas siswa serta dapat memotivasi siswa dalam belajar.

Satu diantara alternatif model pembelajaran yang dipilih penulis dalam penelitian ini adalah Teams Games Tournaments (TGT). Model pembelajaran TGT adalah salah satu jenis dari metode dalam pembelajaran kooperatif. Pembelajaran kooperatif merupakan bentuk pembelajaran dengan cara siswa belajar dan bekerja dalam kelompok-kelompok kecil secara kolaboratif yang anggotanya terdiri dari empat sampai enam orang dengan struktur kelompok yang bersifat heterogen (Rusman, 2012:203). 
Model pembelajaran kooperatif tipe TGT dinyatakan dapat meningkatkan kemampuan pemahaman konsep matematis siswa dan membantu siswa lebih aktif dalam kegiatan pembelajaran, sehingga siswa dapat merespon lebih baik (Astriana dkk, 2017:31). Langkah-langkah guru menyampaikan materi dengan menggunakan model pembelajaran TGT yaitu: (1) penyajian kelas (Class Presentation); (2) Kelompok (Teams); (3) Permainan (Games); (4) Kompetisi/Turnamen (Tournament); (5) penghargaan kelompok dan kesimpulan.

Model pembelajaran TGT diharapkan mampu menjadi solusi untuk meningkatkan kemampuan pemahaman konsep matematis siswa khususnya pada materi himpunan.Berdasarkan uraian tersebut, perlu dilakukan penelitian dengan judul "Efektivitas Model Pembelajaran Kooperatif Tipe Teams Games Tournaments untuk Meningkatkan Pemahaman Konsep Matematis Siswa pada Materi Himpunan."

\section{METODE PENELITIAN}

Jenis penelitian yang digunakan dalam penelitian ini adalah jenis penelitian True Experimental Design dengan pendekatan kuantitatif, karena dalam penelitian ini peneliti dapat mengontrol semua variabel luar. Penelitian ini menggunakan dua kelas yaitu kelas eksperimen dengan menggunakan model pembelajaran TGT dan kelas kontrol dengan menggunakan model pembelajaran langsung. Adapun desain penelitian yang digunakan dalam penelitian ini adalah Pre-test Posttest Control-Group Design.

Adapun populasi dalam penelitian ini adalah semua siswa kelas VII SMP Negeri 9 Singkawang tahun ajaran 2015/2016 yang terdiri dari 4 kelas dan berjumlah 112 orang siswa. Teknik pengambilan sampel yang digunakan dalam penelitian ini adalah dengan teknik Probability Sampling. Pengambilan sampel yang digunakan adalah Simple Random Sampling. Jadi, sampel pada penelitian ini yaitu kelas VII A sebagai kelas eksperimen yang berjumlah 28 orang siswa dan kelas VII B sebagai kelas kontrol yang berjumlah 28 orang siswa.

Teknik pengumpulan data yang dimaksud dalam penelitian ini adalah lembar tes kemampuan pemahaman konsep matematis. Lembar tes yang digunakan yaitu berupa lembar tes awal (Pre-test)dan akhir (Post-test) yang terdiri dari empat butir soal. Selain lembar tes, instrumen yang digunakan dalam penelitian ini adalah lembar pengamatan aktivitas digunakan untuk melihat keterlibatan siswa dalam proses pembelajaran. Angket digunakan untuk mengetahui motivasi belajar siswa dengan menggunakan lembar angket motivasi belajar siswa yang terdiri dari 20 pernyataan berbentuk pilihan ganda dengan memberi tanda silang $(\mathrm{x})$.

Instrumen pengumpulan data yang dimaksud dalam penelitian ini berupa soal tes kemampuan pemahaman konsep matematis, lembar pengamatan, dan lembar angket. Instrumen pengumpulan data berupa tes terlebih dulu di uji validitas, reliabilitas, daya pembeda dan tingkat kesukarannya.Validitas bertujuan agar tes yang digunakan benar-benar untuk mengukur kemampuan siswa dalam menyelesaikan soal himpunan, maka instrumen yang telah disusun diukur dengan validitas tes. Adapun hasil perhitungan validitas dapat dilihat pada Tabel 1.

Tabel 1. Perhitungan Validitas Uji Coba Soal

\begin{tabular}{|c|c|c|c|c|c|c|}
\hline Soal & $\begin{array}{c}\text { Nomor } \\
1\end{array}$ & $\begin{array}{c}\text { Nomor } \\
2\end{array}$ & $\begin{array}{c}\text { Nomor } \\
\text { 3a }\end{array}$ & $\begin{array}{c}\text { Nomor } \\
\text { 3b }\end{array}$ & $\begin{array}{c}\text { Nomor } \\
\mathbf{4 a}\end{array}$ & $\begin{array}{c}\text { Nomor } \\
4 b\end{array}$ \\
\hline Validitas & 0,70 & 0,83 & 0,89 & 0,84 & 0,90 & 0,84 \\
\hline Kriteria & Tinggi & Tinggi & Sangat Tinggi & Sangat Tinggi & Sangat Tinggi & Sangat Tinggi \\
\hline
\end{tabular}

Reliabilitas menunjukkan pada suatu pengertian bahwa suatu instrumen cukup dapat dipercaya untuk digunakan sebagai alat pengumpulan data karena instrumen tersebut sudah baik. Berdasarkan hasil perhitungan uji coba soal diperoleh bahwa reliabilitas sebesar 0,91 dengan kriteria sangat tinggi. Daya pembeda adalah kemampuan dari tes tersebut dalam memisahkan antara subjek yang pandai dengan subjek yang kurang pandai. Adapun hasil perhitungan daya pembeda dapat dilihat pada Tabel 2. 
VARIABEL Vol. 2 No. 1 (2019)

Tabel 2. Perhitungan Daya Pembeda Uji Coba Soal

\begin{tabular}{lcccccc}
\hline \multirow{2}{*}{ Soal } & Nomor & Nomor & Nomor & \multicolumn{2}{c}{ Nomor } & \multicolumn{2}{c}{ Nomor Nomor } \\
& $\mathbf{1}$ & $\mathbf{2}$ & $\mathbf{3 a}$ & $\mathbf{3 b}$ & $\mathbf{4 a}$ & $\mathbf{4 b}$ \\
\hline DP & 0,38 & 0,53 & 0,44 & 0,53 & 0,56 & 0,47 \\
Kriteria & Cukup & Baik & Baik & Baik & Baik & Baik \\
\hline
\end{tabular}

Tingkat kesukaran bertujuan untuk mengkaji soal-soal soal tes yang diujicobakan dari sisi kesulitannya, sehingga dapat diperoleh soal-soal yang termasuk dalam kategori mudah, sedang dan sukar.Adapun hasil perhitungan tingkat kesukaran dapat dilihat pada Tabel 3.

Tabel 3. Perhitungan Tingkat Kesukaran Uji Coba Soal

\begin{tabular}{lcccccc}
\hline \multicolumn{1}{c}{ Soal } & Nomor & Nomor & Nomor & Nomor & Nomor & Nomor \\
& $\mathbf{1}$ & $\mathbf{2}$ & $\mathbf{3 a}$ & $\mathbf{3 b}$ & $\mathbf{4 a}$ & $\mathbf{4 b}$ \\
\hline TK & 0,69 & 0,64 & 0,72 & 0,55 & 0,69 & 0,55 \\
Kriteria & Sedang & Sedang & Mudah & Sedang & Sedang & Sedang \\
\hline
\end{tabular}

\section{HASIL DAN PEMBAHASAN}

Berdasarkan hasil pengumpulan data selama penelitian diperoleh data hasil pretest dan posttest (berupa skor) dari kelas yang diajarkan dengan model pembelajaran TGT untuk kelas eksperimen dan pembelajaran langsung untuk kelas kontrol terhadap kemampuan pemahaman konsep matematis siswa pada materi himpunan. Penilaian kemampuan pemahaman konsep matematis siswa dinilai dari skor rata-rata tiap indikator kemampuan pemahaman konsep matematis siswa dan nilai rata-rata kemampuan pemahaman konsep matematis siswa. Indikator dari dalam penelitian ini antara lain: (a) menyatakan ulang sebuah konsep dengan skor 4; (b) mengklasifikasikan obyek menurut sifat-sifat tertentu dengan skor 4; (c) mengaplikasikan konsep atau algoritma pemecahan masalah dengan skor 4. Dimana terdapat 4 buah soal essay dengan skor total 24. Berdasarkan analisis hasil posttest kemampuan pemahaman konsep matematis siswa pada kelas kontrol dan eksperimen rata-rata skor untuk setiap indikator kemampuan pemahaman konsep matematis siswa dapat dilihat pada Tabel 4.

Tabel 4. Nilai Posttest Kelas Eksperimen dan Kelas Kontrol

\begin{tabular}{lcc}
\hline & Kelas Eksperimen & Kelas Kontrol \\
\hline Rata-Rata & 84,07 & 44,79 \\
Standar Deviasi & 9,08 & 10,58 \\
\hline
\end{tabular}

Berdasarkan Tabel 4, analisis data rata-rata posttest kemampuan pemahaman konsep matematis siswa kelas eksperimen lebih tinggi yaitu sebesar 84,07 dibandingkan rata-rata kemampuan pemahaman konsep matematis siswa kelas kontrol yaitu sebesar 44,79. Selain itu, berdasarkan uji hipotesis menunjukkan bahwa Ho ditolak dan Ha diterima sehingga terdapat perbedaan yang signifikan antara kelas eksperimen yang menggunakan model pembelajaran TGT dan kelas kontrol yang menggunakan model pembelajaran langsung yaitu kemampuan pemahaman konsep matematis siswa kelas ekperimen lebih tinggi dibanding kemampuan pemahaman konsep matematis siswa kelas kontrol.

Hal ini dikarenakan pembelajaran matematika dengan menggunakan model pembelajaran TGT lebih efektif daripada pembelajaran matematika dengan menggunakan model pembelajaran langsung.Perbedaan kemampuan pemahaman konsep matematis siswa disebabkan karena adanya perbedaan yang ditimbulkan oleh masing-masing perlakuan terhadap kemampuan pemahaman konsep matematis siswa.Siswa yang diberi perlakuan dengan menggunakan model pembelajaran TGT mendapat kontribusi lebih baik daripada siswa yang diberi perlakuan dengan pembelajaran langsung.Hasil ini sejalan dengan penelitian yang dilakukan oleh Kirana (2013) yang menyimpulkan bahwa model pembelajaran TGT lebih efektif diterapkan daripada pembelajaran konvensional apabila ditinjau dari pemahaman konsep matematis siswa. 
Berdasarkan perhitungan data aktivitas padalembar pengamatan Aktivitas siswa terhadap model pembelajaran TGT pada materi himpunan di kelas SMP Negeri 9 Singkawang diperoleh rata-rata aktivitas siswa sebesar $80,26 \%$, dengan kategori aktif. Persentase rata-rata aktivitas pada pertemuan pertama dan kedua pada kategori pengamatan visual activities dengan dua aktivitas yang diamati yaitu siswa memperhatikan penjelasan guru dan memperhatikan presentasi kelompokdiperoleh persentase sebesar $73,81 \%$ pada pertemuan pertama dan $88,10 \%$ pada pertemuan kedua. Pada kategori pengamatan oral activities dengan empat akivitas yang diamati yaitu siswa memberikan tanggapan terhadap apa yang guru sampaikan, mengajukan pendapat pada saat diskusi, melaksanakan diskusi dan menambahkan kesimpulan diperoleh persentase sebesar 59,82\% untuk pertemuan pertama dan 74,40\% untuk pertemuan kedua.

Pada kategori listening activities yang tediri dari dua aktivitas yang diamati yaitu siswa menyimak seluruh informasi yang disampaikan guru dan menyimak presentasi kelompok diperoleh persentase sebesar $81,55 \%$ pada pertemuan pertama dan $85,71 \%$ pada pertemuan kedua. Pada kategori pengamatan writing activities yang terdiri tiga aktivitas yang diamati yaitu siswa mencatat hal-hal penting yang disampaikan guru, mencatat kesimpulan materi yang diberikan dan mencatat hasil kesimpulan presentasi diperoleh persentase sebesar $90,87 \%$ pada pertemuan pertama dan $96,03 \%$ pada pertemuan kedua. Pada kategori pengamatan mental activities yang tediri dari dua aktivitas yang diamati yaitu siswa mengerjakan LKS dan mengerjakan soal evaluasi diperoleh persentase sebesar $72,55 \%$ pada pertemuan pertama dan $79,41 \%$ pada pertemuan kedua.

Berdasarkan data persentase aktivitas siswa, diperoleh rata-rata dari enam kategori pengamatan, dua kali pertemuan dan tiga orang observer yaitu sebesar $80,26 \%$. Hal ini menunjukkan bahwa aktivitas siswa selama pembelajaran berlangsung berada pada kategori aktif. Dengan demikian dapat disimpulkan bahwa siswa menjadi aktif pada pembelajaran materi himpunan dengan menggunakan model pembelajaran TGT. Adapun hasil perhitungan aktivitas belajar siswa dapat dilihat di Tabel 5 .

Tabel 5. Hasil Pengamatan Aktivitas Belajar Siswa

\begin{tabular}{lcccc}
\hline Kategori & Pertemuan & Pertemuan & Rata-rata & Kategori \\
Pengamatan & $\mathbf{1}$ & $\mathbf{2}$ & & \\
\hline Visual activities & $73,81 \%$ & $88,10 \%$ & & \\
Oral activities & $59,82 \%$ & $74,40 \%$ & & \\
Listening activities & $81,55 \%$ & $85,71 \%$ & $\mathbf{8 0 , 2 6 \%}$ & Aktif \\
Writing activities & $90,87 \%$ & $96,03 \%$ & & \\
Mental activities & $72,55 \%$ & $79,41 \%$ & & \\
Rata-rata & $\mathbf{7 5 , 7 2 \%}$ & $\mathbf{8 4 , 7 3 \%}$ & & \\
\hline
\end{tabular}

Berdasarkan Tabel 5 hasil pengamatan aktivitas belajar siswa dengan model pembelajaran TGT yang dilakukan sebanyak dua kali pertemuan diperoleh rata-rata persentase pada pertemuan 1 (satu) yaitu $75,72 \%$ sedangkan pertemuan 2 (dua) yaitu 84,73\% dengan rata-rata keseluruhan pertemuan keduanya adalah $80,26 \%$ dengan kategori aktif. Hal ini menunjukkan bahwa aktivitas siswa selama pembelajaran berlangsung berada pada kriteria aktif. Dengan demikian dapat disimpulkan bahwa siswa menjadi aktif pada pembelajaran materi himpunan dengan menggunakan model pembelajaran TGT. Hal ini menunjukkan bahwa model pembelajaran TGT berpengaruh positif sehingga aktivitas siswa menjadi aktif pada pembelajaran materi himpunan.Hasil ini sejalan dengan penelitian yang dilakukan oleh Astriana dkk (2016) yang menyimpulkan bahwa aktivitas siswa yang memperoleh model pembelajaran matematika tipe TGT lebih baik daripada siswa yang memperoleh pembelajaran langsung.

Berdasarkan motivasi belajar siswa pada materi himpunan dengan model pembelajaran TGT diperoleh rata-rata jumlah skor total seluruh indikator motivasi belajar sebesar 74,17 dengan kategori tinggi. Adapun hasil perhitungan motivasi belajar siswa dapat dilihat di Tabel 6. 
VARIABEL Vol. 2 No. 1 (2019)

Page: $9-15$

Tabel 6. Hasil Angket Motivasi Belajar Siswa

\begin{tabular}{lcc}
\hline \multicolumn{1}{c}{ Indikator Motivasi Belajar } & $\begin{array}{c}\text { Skor Total Rata-rata } \\
\text { Seluruh Siswa Disetiap } \\
\text { Indikator (Mt) }\end{array}$ & Kriteria \\
\hline Hasrat dan keinginan berhasil & 75 & Tinggi \\
Dorongan dan kebutuhan dalam belajar & 68 & Cukup \\
Harapan dan cita-cita masa depa & 85 & Sangat Tinggi \\
Penghargaan dalam belajar & 65 & Cukup \\
Kegiatan menarik dalam belajar & 77 & Tinggi \\
Lingkungan belajar yang kondusif & 75 & Tinggi \\
$\quad$ Jumlah & $\mathbf{4 4 5}$ & Tinggi \\
\hline
\end{tabular}

Adapun untuk motivasi belajar siswa dilihat dari angket terdiri dari beberapa indikator yaitu; (1) hasrat dan keinginan berhasil; (2) dorongan dan kebutuhan dalam belajar; (3) harapan dan cita-cita masa depan; (4) penghargaan dalam belajar; (5) kegiatan menarik dalam belajar; (6) lingkungan belajar yang kondusif. Berdasarkan hasil perhitungan angket motivasi belajar dengan indikator harapan dan cita-cita masa depan yang diperoleh motivasi belajar siswa sangat tinggi. Untuk indikator hasrat dan keinginan berhasil, kegiatan menarik dalam belajar, dan lingkungan belajar yang kondusif yang diperoleh dari tiga indikator tersebut motivasi belajar siswa tinggi, serta pada indikator dorongan dan kebutuhan dalam belajar dan penghargaan dalam belajar yang diperoleh yaitu motivasi belajar siswa cukup.

Selain itu, jika dilihat dari motivasi belajar siswa terhadap setiap butir pernyataan, diperoleh rata-rata jumlah skor total seluruh indikator motivasi belajar diperoleh rata-rata skor total sebesar 74,17 dengan kriteria motivasi belajar siswa tinggi. Sehingga, dengan demikian dapat disimpulkan bahwa motivasi siswa pada materi himpunan dengan model pembelajaran TGT adalah tinggi. Hal ini menunjukkan bahwa motivasi belajar siswa tinggi dikarenakan proses pembelajaran dengan menggunakan model TGT pada materi himpunan. Hasil ini sejalan dengan penelitian yang dilakukan oleh Nuha (2009) yang menyimpulkan bahwa dengan diterapkannya model pembelajaran TGT dapat meningkatkan motivasi belajar siswa.

\section{KESIMPULAN}

Berdasarkan analisis data hasil penelitian dapat disimpulkan bahwa model pembelajaran TGT efektif diterapkan untuk meningkatkan kemampuan pemahaman konsep matematis siswa pada materi himpunan di kelas SMP Negeri 9 Singkawang. Dikatakan efektif, karena secara khusus telah memenuhi beberapa hal sebagai berikut. (1) Berdasarkan analisis data yang diperoleh bahwa $t_{\text {hitung }}=16,44>t_{\text {tabel }}=2,00$, sehingga terdapat perbedaan peningkatan kemampuan pemahaman konsep matematis siswa di kelas kontrol dan di kelas eksperimen pada materi himpunan di kelas SMP Negeri 9 Singkawang. (2) Aktivitas siswa terhadap model pembelajaran TGT pada materi himpunan di kelas SMP Negeri 9 Singkawang diperoleh rata-rata sebesar 80,26\%, dengan kategori aktif. (3) Motivasi belajar siswa pada materi himpunan dengan model pembelajaran TGT diperoleh rata-rata sebesar 74,17 dengan kategori tinggi.

\section{DAFTAR PUSTAKA}

Astriana, M. Murdani, E. dan Mariyam. (2017). Penerapan Model Pembelajaran Kooperatif Tipe Teams Games Tournament untuk Meningkatkan Kemampuan Pemahaman Konsep Matematis pada Materi Operasi Bilangan Pecahan. Jurnal Pendidikan Matematika Indonesia, 2(1): 27-31.

Hendriana, H. dan Soemarmo, U. (2014). Penilaian Pembelajaran Matematika. Bandung: PT Refika Aditama. 
Isrotun, U. (2014). Peningkatan Pemahaman Konsep Matematika Melalui Penerapan Pembelajaran Realistik. Skripsi. Universitas Muhammadiyah Surakarta. Tidak Dipublikasikan.

Jihad, A. dan Haris, A. (2008). Evaluasi Pembelajaran. Yogyakarta: Multi Pressindo.

Kirana, A. (2013). Efektivitas Penerapan Model Pembelajaran Kooperatif Tipe TGT Ditinjau Dari Pemahaman Konsep Matematis Siswa. Jurnal Pendidikan Matematika. 2(2).

Nuha, A. (2009). Penerapan Model pembelajaran kooperatif tipe TGT dalam materi pokok logaritma guna meningkatkan motivasi belajar dan hasil belajar peserta didik kelas X A MAN Semarang 2 Semester Gasal Tahun Pelajaran 2009/2010. Skripsi. Institut Agama Negeri Walisongo. Tidak Dipublikasikan.

Rusman. (2012). Model-model Pembelajaran: Mengembangkan Profesionalisme Guru. Jakarta: PT Raja Grafindo Persada. 